\title{
Wave Energy Potential Assessment during Recent Extreme Events Observed on Benin's Coastal Area, Gulf of Guinea (West Africa).
}

\author{
G. H. HOUNGUÈ ${ }^{1,2,3}$, M. A. HOUÉPKONHÉHA ${ }^{2,4}$, N. B. TOKPOHOZIN 2,4 \\ and B. B. KOUNOUHÉWA ${ }^{1,2,3}$
}

\author{
${ }^{1}$ Département de Physique (FAST) et Formation Doctorale Sciences des Matériaux (FDSM), Université d'Abomey- \\ Calavi, Bénin. \\ ${ }^{2}$ Laboratoire de Physique du Rayonnement (LPR), FAST-UAC, 01 BP 526 Cotonou, Bénin. \\ ${ }^{3}$ Institut des Recherches Industrielles, Technologiques et en Sciences Exactes (IRITESE/CBRSI), Bénin. \\ ${ }^{4}$ Institut de Mathématique et de Sciences Physiques (IMSP), Dangbo, Bénin. \\ Corresponding author: hguyherv@gmail.com
}

\section{INFOS SUR L'A R T I C L E}

Historique de l'article:

Reçu le : 31 juillet 2019

Reçu en format revisé le : 31 décembre 2019

Accepté le : 31 décembre 2019

Keys words: Wave energy, Extreme events,

ERA Reanalysis, Benin, Gulf of Guinea.

\section{A B S T R A C T}

\begin{abstract}
The coast of Benin has been subject for several years to a series of extreme wave with consequences, the collapse of buildings, the displacement of the population, the early cessation of fishing activities. In this paper, we assessed extreme wave energy potential in Benin coastal area during extremes events from sixteen years ERA reanalysis of European Center for Medium-Range Weather Forecasts (ECMWF) data sets and buoy ALIZE data sets deployed offshore about $6 \mathrm{Km}$ from the Autonomous port of Cotonou (Benin). The results show that period from May to September is the extremes wave period with $77 \%$ of occurrence, with May, July and September, the months of greatest occurrences. Wave energy in Benin coastal area during this period is evaluated at $646.26 \mathrm{MWh} / \mathrm{m}$ and constitutes an important resource that can help the country for its energy self-sufficiency.
\end{abstract}

\section{INTRODUCTION}

Wave energy is a potential source of energy that can solve both the energy-security and coastal-protection problems affecting coastal societies (Manasseh et al., 2017). Indeed, recovery devices used for wave energy extraction are particularly interesting since they partially absorb waves in producing electricity and may thus reduce the wave energy incident on the littoral (Mendoza et al., 2014). These devices have shown their importance in coastal protection around the world and have contributed to the energy self-sufficiency of coastal countries (Chang et al., 2016, Felix et al., 2018). Knowledge of extreme swells during storm events is a very important element for a better evaluation of the energy but also for the dimensioning of recovery devices. A large amount of energy is often carried by swell during these storms and affects the coasts. As a result, homes are often destroyed, and populations displaced. Reducing greenhouse gas emissions generated by the burning of fossil fuels, could go using clean energy sources such as wave energy.

Benin's coastline has for several years been subject to a series of extreme swells, resulting in the collapse of buildings, the displacement of the population and the early cessation of fishing activities. At the same time, the country is one of the countries with low access to energy (27\%) (DGE, 2017) with a quasi-dependence from the outside (Houékpohéha et al., 2015). Hounguè et al, 2018(b), showed that Benin's coastline dynamics is strongly correlated with wave energy variability breaking on this coast. It would be interesting for this fact to know the period of these extreme events to deduce the energy to which the coast of Benin is exposed.

The goal of this work is to assess wave energy potential during the recent extreme events observed in the Benin coastal zone.

\section{MATERIALS AND METHODS}

\section{II.1. Study area}

Benin's coastline, $125 \mathrm{~km}$ long, located between the longitudes $\mathrm{E} 1^{\circ} 5$ and $2^{\circ} 5 \mathrm{E}$ and the latitudes $5^{\circ} \mathrm{N}$ and $6^{\circ} \mathrm{N}$ is facingSouth Atlantic Ocean (Fig. 1a). It is an open environment exposed to long swell waves and dominated by moderate energy waves influence (mean significant wave height $\mathrm{Hs}=1.36 \mathrm{~m}$, mean peak period $\mathrm{Tp}=9.4 \mathrm{~s}$ ) coming from mid-to high latitudes $\left(45-60^{\circ}\right)$ in the South Atlantic as well as locally generated short-waves in the tropical band (latitude $6^{\circ} \mathrm{N}$ to longitude $15^{\circ} \mathrm{S}$ ) with an S- 
SW incidence (incidence on the coast between 4 and $10^{\circ}$ ) (Laïbi et al., 2014).

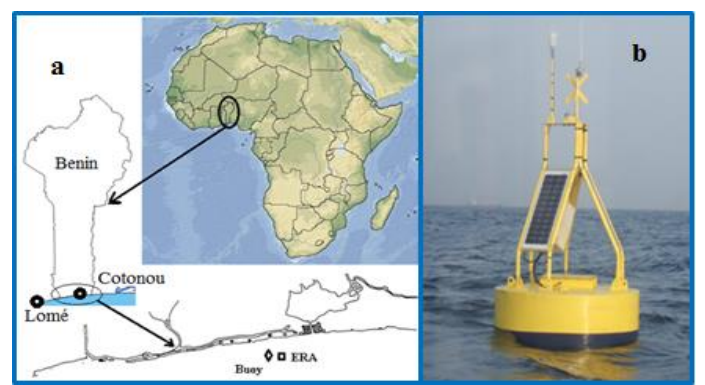

Fig. 1: Study area, Benin's coastal zone (fig. 1.a) and ALIZE buoy at sea (fig. 1.b)

\section{II.2. Data}

\section{II.2.1. Buoy data}

Wave parameters data from buoy deployed offshore about $6 \mathrm{Km}$ from Autonomous port of Cotonou and more than $15 \mathrm{~m}$ deep at the coordinates (latitude $6^{\circ} 18^{\prime} 49 \mathrm{~N}$, longitude $2^{\circ} 28^{\prime} 46 \mathrm{E}$ ) are used (Fig. 1b). Waves parameters, significant wave height $(\mathrm{Hs})$ and peak period (Tp) are recorded every $30 \mathrm{~min}$. The buoy data are used for ERA data validation and cover the period from December 2015 to October 2016 (See Hounguè et al., 2018(c), for more descriptions).

\section{II.2.2. ERAI reanalysis}

Simulations used were provided by ERA reanalysis (ERA40 $2^{\circ} 5^{*} 2^{\circ} 5$ from 1957 to 2002 and ERA-Interim $1.5^{\circ} \times 1.5^{\circ}$ from 2002 to 2016$)$ of the European Center for Medium-Range Weather Forecasting (ECMWF). ERA datasets have always been used and validated in the Gulf of Guinea (Almar et al., 2015). Wave parameters used in this work are Hs (significant wave height in meter) and Tp (wave peak period in second). These parameters are stored four times a day.

\section{II.3. Methods}

\section{II.3.1. Extreme waves modeling}

Hounguè et al, 2018 have analyzed wave extreme condition in Benin coastal area and defined the relationship (1) for their characterization.

$H s>\langle H s(t)\rangle+1,6 * \sigma(H s(t))(1)$

Where $\langle\mathrm{Hs}(\mathrm{t})\rangle=\frac{1}{\mathrm{~N}} \sum_{\mathrm{i}=1}^{\mathrm{N}} \mathrm{Hs}(\mathrm{t}), \sigma$ is the standard deviationHs $(\mathrm{m})$, the significant wave height and $\mathrm{N}$, the element's number in the dataset.

\section{II.3.2. Wave energy potential $P$ in shallow water}

Shallow water correction is considered for wave power density $\mathrm{P}(\mathrm{W} / \mathrm{m})$ in medium water depths $\mathrm{h}$, characterised by $(1 / 20<\mathrm{h} / \lambda<1 / 2)$, with $\lambda$, the wavelength. In this area, wave energy density $\mathrm{P}(\mathrm{W} / \mathrm{m})$ can be calculated as (Wang and Lu, 2009):

$P=\bar{E}\left(\frac{g T_{e}}{2 \pi}(\tanh (k h))^{\frac{1}{2}}\right) *\left[\frac{1}{2} *\left(1+\frac{2 k h}{\sinh (2 k h)}\right)\right]$

with

$\bar{E}=\frac{1}{16} \rho g H_{s}^{2}$

where $\bar{E}\left(\mathrm{~J} / \mathrm{m}^{2}\right)$, denotes wave energy density; $\mathrm{H}_{\mathrm{s}}$, significant wave height; $\rho$, seawater density (assumed to be $\left.1025 \mathrm{~kg} \cdot \mathrm{m}^{3}\right) ; \mathrm{g}$, the gravitational acceleration (assumed to be $9.81 \mathrm{~N} . \mathrm{kg}^{-1}$ ); $\mathrm{k}$, wave number and h, water depth.

\section{II.3.3. Wave energy ressource $E_{T}$ assessment}

Total wave energy resource at extraction point is calculated using Equation (4) which using the probability occurrence of having certain $\mathrm{Hs}$ and Tp (Yaakob et al, 2016)

$$
E_{T}=P_{m} * t_{h}
$$

with $P_{m}=\sum P *$ Prob and $\mathrm{t}_{\mathrm{h}}$, number of hours during considered period.

\section{RESULTS AND ANALYSIS}

\section{III.1. Extreme waves frequencies analysis at interannual scale}

Figure 2 illustrates the interannual variation of extremes wave observed in the coastal zone of the country, obtained from relation (1). There is a strong variability in the occurrence of extremes in different years. An important frequency was noted between 1992 and $2016(73.5 \%)$ and a tendency to increase since 1957 is observed. The years 1992, 1993 and the period from 2000 to 2011 are the years of strong occurrences. Since 2012, a fairly significant increase has been observed in the number of strong swells. Its signature on the Beninese coasts is very remarkable and can be explained by the destruction of the numerous houses and the displacement of the populations noted on various sectors of the Beninese littoral.

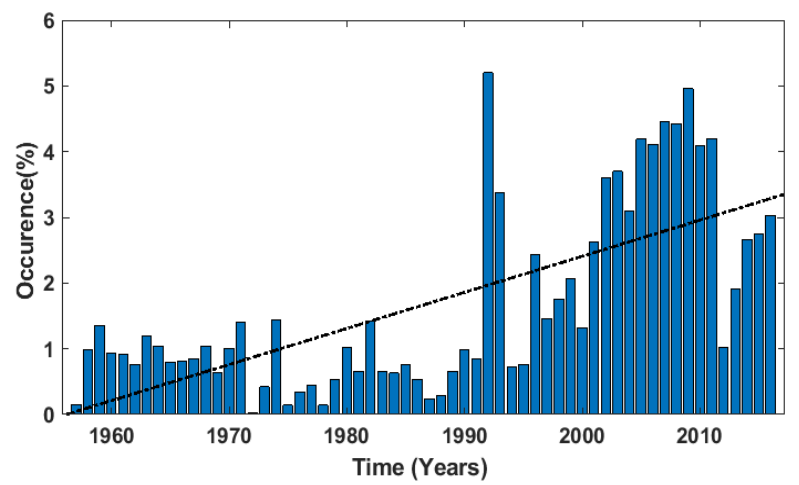

Fig. 2: Occurrence of extremes at the inter-annual scale 


\section{III.2. Extreme waves frequencies analysis at seasonal scale}

Fig. 3 illustrates the intra-annual evolution of the extremes of swells observed in the coastal zone of the country, obtained from the relation (1). At seasonal scale, a high frequency of extremes is observed between May and September, with more than $77 \%$, with peaks in May, July and August respectively of $16 \%, 18 \%$ and $17 \%$. From analysis of the curve, it appears that the period from May to September is that during which we observe the extremes of swells on the coasts of Benin. This period is characterized by gales observed in the South Atlantic and also in the Gulf of Guinea. The period observed in this study is that of strong swells generated in Gulf of Guinea and further south, in south Atlantic (Hounguè et al, 2018 (c)) and is related to wind variability in Gulf of Guinea (Laibi, 2011),

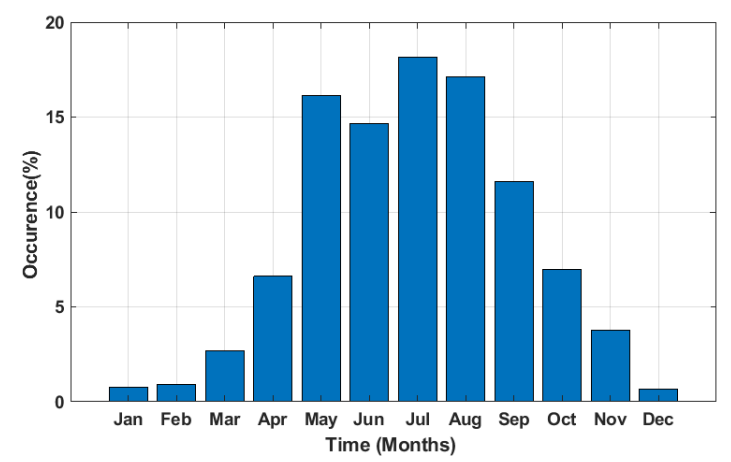

Fig. 3: Occurrence of extremes at the intra-annual scale

\section{III.3. Wave energy potential during extreme wave period}

Fig. 4 illustrates the variation of wave energy potential during the period of wave extremes obtained from the analysis of fig. 3, evaluated using formula (2). During this period, significant height varied from $0.5 \mathrm{~m}$ to $3.5 \mathrm{~m}$ with an average of $2 \mathrm{~m}$ and, for peak period a variation from 5.5 to $15.35 \mathrm{~s}$ is observed with an average of $10.95 \mathrm{~s}$.

Wave energy density during extreme wave condition ranging from 10 to $664.78 \mathrm{KW} / \mathrm{m}$ with an average of $179.65 \mathrm{~kW} / \mathrm{m}$.

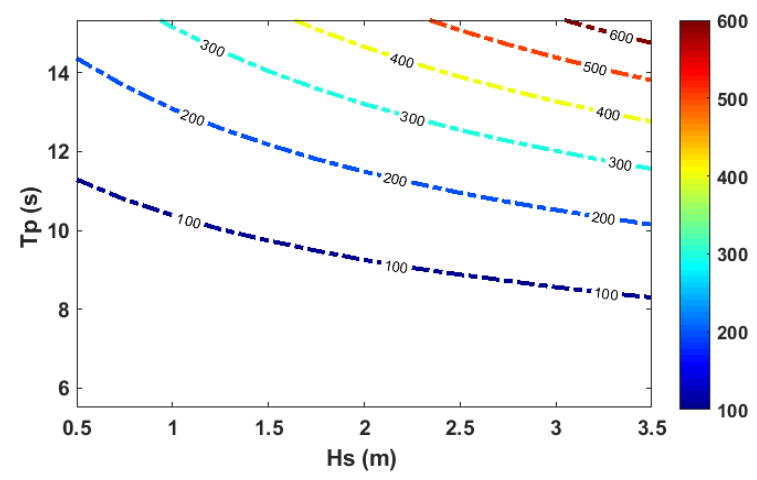

Fig. 4: Wave energy resource in terms of energy available in the coastal zone during extreme events

\section{III.4. Wave energy resource during extreme events}

Wave energy resource during wave extreme event is assessed using formula (4) and is evaluated at 646.26 $\mathrm{MWh} / \mathrm{m}$. This resource is very important for Benin's country since it can participate at its energy independence.

Table 1: Wave energy resource in Benin coastal area during wave extreme events

\begin{tabular}{lll}
\hline $\begin{array}{l}\text { Probability of } \\
\text { exploitable }\end{array}$ & $\begin{array}{l}\text { Wave energy } \\
\text { storage }(\mathrm{MWh} / \mathrm{m})\end{array}$ & Status \\
SWH $(\%)$ & &
\end{tabular}

\begin{tabular}{lll}
\hline 98.79 & 646,26 & Available \\
\hline
\end{tabular}

SWH denotes, significant wave height.

\section{CONCLUSION}

Extreme wave energy potential in Benin coastal area during extremes events has been evaluated using sixteen years ERA reanalysis of European Center for MediumRange Weather Forecasts (ECMWF) and buoy deployed offshore about $6 \mathrm{Km}$ from the Autonomous port of Cotonou (Benin) and more than $15 \mathrm{~m}$ deep at the coordinates $\left(2^{\circ} 28^{\prime} 46 \mathrm{E}, 6^{\circ} 18^{\prime} 49 \mathrm{~N}\right)$ wave data sets.

The analysis showed that the period from May to September is that of extreme swells with more than 77\% of occurrence, the months of May, July and August having the highest occurrences. The energy released by extreme wave during this period is estimated on average at $646.26 \mathrm{MWh} / \mathrm{m}$ and is a fairly important resource that can help the country for its energy self-sufficiency.

\section{ACKNOWLEDGEMENT}

The authors are indebted to IRHOB for buoy data. We acknowledge use of the ECMWF ERA and ERA Interim dataset (www.ECMWF.Int/research/Era).

\section{REFERENCES}

Manasseh R., Sannasiraj S. A., McInnes K. L., Sundar V. and Jalihal P., 2017. Integration of wave energy and other marine renewable energy sources with the needs of coastal societies. International Journal of Ocean and Climate Systems, 2017, Vol. 8 (1), pp. 19 36

Chang G., Ruehl K., Jones C. A., Roberts J., Chartrand C., 2016. Numerical modelling of the effects of wave energy converters characteristics on nearshore wave conditions. Renewable Energy, 89, pp. 636-648

Felix A., Mendoza E., Chávez V., Silva R. and RivillasOspina G., 2018. Wave and wind energy potential including extreme events: A case study of Mexico.Journal of Coastal Research, SI ${ }^{\circ} 85$, pp. 1336-1340. 
Direction Générale de l'Energie (DGE)., 2017. Système d'Information Energétique du Bénin - Rapport annuel 2015 et évolution 2010-2015. French.

Houékpohéha A. M., Kounouhéwa B. B., Hounsou J. T., Tokpohozin B. N., Hounguèvou J. V. and Awanou C. N., 2015. Variations of wave energy power in shoaling zone of Benin coastal zone. International, Journal of Renewable Energy Development, Vol. 4, $\mathrm{n}^{\circ} 1$, pp. 64-71.

Hounguè G. H., Kounouhéwa B. B., Houékpohéha A. M., Tokpohozin N. B. and Madogni V. I., 2018(a). Wave Energy Resources Assessment Offshore Benin from ERA Re-Analysis: Gulf of Guinea, PSIJ, Vol. 19, $\mathrm{n}^{\circ} 4$, pp. 1-11.

Hounguè G. H., Kounouhéwa B. B., Houékpohéha A. M., Tokpohozin N. B., Madogni V. I. and Almar R., 2018(b). Wave Energy Impact on Benin's Coastline Dynamics, Gulf of Guinea. CJAST, Vol. 34, $\mathrm{n}^{\circ} 1$, pp. $1-12$.

Wang C. and Lu W., 2009. Analysis Methods and Reserves Evaluation of Ocean Energy Resources (in Chinese), Beijing: China Ocean Press, pp. 61-62

Almar R., Kestenare E., and Reyns J., 2015. Response of the Bight of Benin (Gulf of Guinea, West Africa) coastline to anthropogenic and natural forcing, Part1: Wave climate variability and impacts on the longshore sediment transport. Continental Shelf Research, Vol. 110, pp. 48-59.

Laibi R., Anthony E., Almar R., Castelle B. and Senechal N., 2014. Alongshore drift cell development on the human-impacted Bight of Benin sand barrier coast, West Africa. In Proceedings 13th International Coastal Symposium (Durban, South Africa), Journal of Coastal Research, Special Issue n 70, pp. 78-83.

Houngue G. H., Kounouhéwa B. B., Almar R., Sohou Z., Lefebvre J. P., Houépkohéha A. M. and Tokpohozin B., 2018(c). Waves forcing climate on Benin coast, and the link with climatic index, Gulf of Guinea (West Africa). Journal of Coastal Research, SI n ${ }^{\circ} 81$, pp. 130-137

Yaakob O., Hashim F. E., Omar K. M., Md Din A. H. and Koh K. K., 2016. Satellite-based wave data and wave energy resource assessment for South China Sea, Renewable Energy, Vol. 88, pp. 359-371.

Mendoza E., Silva R., Zanuttigh B., Angelelli E., Lykke A. T., Martinelli L., Nørgaard J. Q. H. and Ruol P., 2014. Beach response to wave energy converter farms acting as coastal defense. Coastal Engineering, Vol. 87, pp. 97-111.

Laibi, R., 2011. Dynamique actuelle d'une embouchure fluviale estuarienne à flèche sableuse : la bouche du Roi, Bénin, Golfe de Guinée. Thèse de Doctorat des Universités UAC et ULCO, pp.100. 